\title{
Genetic divergence in common bean landrace cultivars from Mato Grosso do Sul State ${ }^{1}$
}

\section{Divergência genética em cultivares tradicionais de feijão do Estado de Mato Grosso do Sul}

\author{
Marco Antonio Aparecido Barelli ${ }^{1}$; Maria Celeste Gonçalves-Vidigal ${ }^{*}$; \\ Pedro Soares Vidigal Filho ${ }^{2}$; Leonarda Grillo Neves ${ }^{1}$; Heloisa Torres da Silva ${ }^{3}$
}

\begin{abstract}
The present study had as objective to evaluate of the genetic divergence among 35 landraces of common bean. The experimental design was carried out in a randomized block with four repetitions. The variance analysis revealed significant difference at 1 and $5 \%$ levels of probability for the evaluated characteristics. The Cluster analysis based in the morpho-agronomic traits presented difference among Andean and Mesoamerican landrace cultivars, which it allocated the landrace cultivars in different groups. The Tocher and the Nearest Neighbor methods demonstrated that the most dissimilars cultivars were Carioca sem Cipó and Jalo, whereas Roxinho Mineiro and Carioca sem Cipó cultivars were the more similars. The first two canonic variables were sufficient to explain about $81.90 \%$ of the total variation showed in this study. These results reveal large genetic diversity among the landraces from Mato Grosso do Sul state.
\end{abstract}

Key words: Phaseolus vulgaris, multivariate analysis, morpho-agronomic traits

\section{Resumo}

O presente estudo teve como objetivo avaliar a divergência genética entre 35 cultivares tradicionais de feijão. O delineamento experimental foi realizado em blocos casualizados com 4 repetições. A análise de variância revelou diferença significativa ao nível de 1 e 5\% de probabilidade para as características avaliadas. A análise de agrupamento baseada nas características morfo-agronômicas apresentou diferença entre as cultivares crioulas Andina e Mesoamericana, o qual alocou as cultivares crioulas em grupos diferentes. Os métodos de Tocher e Vizinho Mais Próximo demonstraram que as cultivares mais dissimilares foram a Carioca sem Cipó e Jalo, enquanto que Roxinho Mineiro e Carioca sem Cipó foram as mais similares. As duas primeiras variáveis canônicas foram suficientes para explicar cerca de $81,90 \%$ da variação total observada neste estudo. Os resultados revelaram uma ampla diversidade genética entre as cultivares tradicionais do estado do Mato Grosso do Sul.

Palavras-chave: Phaseolus vulgaris, análise multivariada, características morfo-agronômicas

1 Professor, Dr., Departamento de Agronomia, Universidade do Estado de Mato Grosso, Mato Grosso, MT.

2 Professor, Dr., Departamento de Agronomia, Universidade Estadual de Maringá, Maringá, PR. mvidigal@pop.com.br

Pesquisadora, Dr., Centro Nacional de Pesquisa em Arroz e Feijão - Embrapa, Santo Antonio de Goiás, GO.

4 Aluno de Pós-graduação, Eng $^{\circ}$ Agr $^{\circ}$., Universidade Estadual de Maringá, Maringá, PR.

* Autor para correspondência 


\section{Introduction}

The common bean (Phaseolus vulgaris L.) is one of the most important sources of protein for many people living in tropical and sub-tropical regions, especially in several Latin American countries (TANDON et al., 1957). In Brazil the common bean is the most important grain legume consumed as a food source (SGARBIERI; ANTUNES; ALMEIDA, 1979; VIEIRA, 1992).

The wide genetic variability of the common bean is organized in two main germplasm groups, represented by the Mesoamerican (small seeds) and Andean (large seeds) domestication centers (SINGH; GEPTS; DEBOUCK, 1991; MCCLEAN; MYRES; HAMMOND, 1993). These groups have been subdivided into races, based principally on morphological, agronomic and biochemical assessments of the corresponding germplasm (SINGH et al., 1991). There is a varied preference choices made by consumers and growers, and especially the environmental conditions where this crop is exploited has caused wide genetic variability in the common bean germplasm. This fact reveals that the information about inter species diversity and genetic divergence is essential for the reasonable use of genetic sources (GONÇALVES; MIRANDA, 1983; LOARCE; GALLEGO; FERRER, 1996) in addition to being important for the success of all principal economic breeding programs.

Research on genetic divergence is very important for breeding programs because it gives parameters for the identification of divergent parents, enabling superior genotypes to be obtained in segregant populations.

The landraces of the common bean have shown wide genetic variability for seed color, shape, brightness, size (in general large seeded cultivars are preferred), among other characteristics of cultivars used by farmers. These cultivars have demonstrated adaptability to several environmental conditions, which can be observed through the resistance to diseases and high yield potential (RODIÑO et al., 2003).

Multivariate statistical methods have been used previously to analyze patterns of genetic diversity (PEREIRA; VENCOVSKY; CRUZ, 1992). In agreement with Johnson e Wickern (1988) recommended the use of a set of genotypic and phenotypic traits to obtain information on genetic dissimilarity the use of multivariate statistics, which include canonic variables, principal component analysis and the cluster methods by Tocher and Single Linkage (CRUZ; REGAZZI, 1994). These have been widely used to characterize the common bean (BEEBE et al., 2000; BEEBE et al., 2001; ISLAM et al., 2002; RIBEIRO; STORCK, 2003; TEIXEIRA et al., 2004; CHIORATO et al., 2005; DURÁN et al., 2005; MIRANDA-LORIGADOS et al., 2006).

The aim of this research was to study the genetic diversity in the land race $P$. vulgaris L. cultivars that have been grown in Mato Grosso do Sul State, using morphological and agronomic traits.

\section{Material and methods}

Plant material and experiment localization

The Thirty-five common bean landraces used in this study were obtained in the Mato Grosso do Sul State (Table 1), in which are remained in the Active Germplasm Bank (BAG) at the Brazilian Corporation for Agricultural Research (Embrapa). The experiment was carried out in the Cáceres town, in an area belonging to Empresa Mato-grossense de Pesquisa, Assistência e Extensão Rural during the 2003/2004 season. 
Table 1. Identification number, local name and key traits of the 35 landraces of the common bean from Mato Grosso do Sul state

\begin{tabular}{|c|c|c|c|c|c|}
\hline Identification & Local name & $\begin{array}{c}\text { Flower } \\
\text { color }\end{array}$ & Growth habit & Seed color & Shine of seed \\
\hline 1 & Rosinha Opaco & White & Determinate Type I & Pink & Opaque \\
\hline 2 & Rosinha A & White & Indeterminate Type II & Pink & Shiny \\
\hline 3 & Roxinho A & White & Indeterminate Type II & Beige/Purple & Opaque \\
\hline 4 & Carioquinha Limpo & White & Indeterminate Type III & Beige & Opaque \\
\hline 5 & Rosado & White & Indeterminate Type II & Pink & Opaque \\
\hline 6 & Roxinho B & White & Determinate Type I & Purple & Intermediate \\
\hline 7 & Mulatão Lustroso & White & Determinate Type I & Brown & Intermediate \\
\hline 8 & Bico de ouro A & Violet & Indeterminate Type II & Beige & Opaque \\
\hline 9 & Mulatinho Vagem Roxa B & Violet & Indeterminate Type II & Beige & Opaque \\
\hline 10 & Carioca Bagem Rosada & White & Indeterminate Type III & Beige & Opaque \\
\hline 11 & Jalo & Violet & Determinate Type I & Yellow & Opaque \\
\hline 12 & Manteiguinha & Violet & Determinate Type I & Yellow & Intermediate \\
\hline 13 & Uberabinha Preto & Violet & Indeterminate Type II & Black & Opaque \\
\hline 14 & Manteiguinha de Cipó & Bicolor & Determinate Type I & Brown & Shiny \\
\hline 15 & Carioca Novo & White & Determinate Type I & Beige & Opaque \\
\hline 16 & Jalo sem Cipó & Bicolor & Determinate Type I & Beige & Shiny \\
\hline 17 & Carioca sem Cipó & Bicolor & Determinate Type I & Beige & Opaque \\
\hline 18 & Bodoquena & White & Determinate Type I & Beige/Pink & Opaque \\
\hline 19 & Chita Bonita & White & Determinate Type I & Beige/Pink & Opaque \\
\hline 20 & Rosinha sem Cipó & Pink & Determinate Type I & Beige & Shiny \\
\hline 21 & Manteiga sem Cipó & Bicolor & Determinate Type I & Yellow & Shiny \\
\hline 22 & Manteiga com Cipó & White & Indeterminate Type III & Beige & Opaque \\
\hline 23 & Carioca com Cipó & White & Determinate Type I & Beige & Shiny \\
\hline 24 & Bolinha & Violet & Indeterminate Type II & Beige & Opaque \\
\hline 25 & Mulatinho Vagem Roxa B & White & Determinate Type I & Pink & Opaque \\
\hline 26 & Rosinha B & White & Indeterminate Type II & Yellow & Intermediate \\
\hline 27 & Roxinho Mineiro & White & Indeterminate Type II & Purple & Opaque \\
\hline 28 & Preto Guamirim & Violet & Indeterminate Type II & Black & Opaque \\
\hline 29 & Mantegão & Pink & Determinate Type I & Yellow & Intermediate \\
\hline 30 & Rosinha C & White & Indeterminate Type II & Pink & Intermediate \\
\hline 31 & Rosinha Guaicurus & White & Determinate Type I & Pink & Opaque \\
\hline 32 & Cara Suja & White & Determinate Type I & Brown & Opaque \\
\hline 33 & Mantega & Bicolor & Determinate Type I & Beige & Intermediate \\
\hline 34 & Bico de Ouro B & White & Indeterminate Type II & Beige & Shiny \\
\hline 35 & Rosinha D & White & Determinate Type I & Beige & Opaque \\
\hline
\end{tabular}




\section{Evaluated characteristics}

The following characteristics were assessed: a) Number of days to emergence (MNDE): assessed as the average of the number of days from sowing to the rising of the cotyledon at soil level of all plants in each treatment; b) Number of days to flowering (NDF): obtained by counting the number of days, from sowing to the complete opening of the first flower, of $50 \%$ of the plants in each treatment; c) Mean insertion height of the first pod (MHFPI): expressed in $\mathrm{cm}$, as the ratio between the measurement from the soil to the insertion of the first pod and the respective number of plants in each treatment; d) Mean longitudinal length of the pods (MLLP): obtained by measuring the pod length from one longitudinal extremity to the other, in a random sample of ten pods from each treatment; e) Total number of pods per plant (TNPP): obtained by total count of pods produced per plant, in each treatment; f) Total number of seeds per plant (TNSP): obtained the ratio between the total number of seeds and the total number of pods produced per plant, in each treatment; g) Mean number of seeds per pod (MNSP): obtained by total count of seeds per pod; $h$ ) Mean 100 seed weight (MSW): expressed in grams, obtained by weighting a sample of fifty seeds from each treatment and multiplied by 2; and i) Cycle: number of days from sowing to the harvest, when $90 \%$ of the pods presented physiological maturity.

\section{Experimental design}

The experimental design was in randomized complete block with four repetitions, in which each experimental unit was made up of four $2 \mathrm{~m}$ long rows spaced at 0.6 meters. The useful plot area consisted of the two central rows, leaving a total of $2.4 \mathrm{~m}^{2}$, with 48 plants.

\section{Data analysis}

The data obtained were submitted to variance analysis and the values of each observation were given by the mentioned statistics method, as well as the genotype effects were considered fixed.

The landraces were clustered by the Tocher method and Nearest Neighbor method, using the Genes statistics program (CRUZ, 2006). The Tocher method requires the dissimilarity matrix, on which is identified the most similar pair of individuals, composing the initial group. Then, the possibility of the inclusion of new individuals is evaluated, adopting the requirement that the average intragroup distance must be lower than the average intergroup distance (CRUZ; CARNEIRO, 2003).

According to Cruz and Carneiro (2003), one group always increases the average distance value with the addition of an individual. The inclusion of one genotype in one group is made by comparing the average distance value of the group and the maximum level allowed.

In the present study the genetic diversity was estimated using the Mahalanobis distance $D_{i i^{\prime}}^{2}$, which is based on the quantification of the relative contribution of the genetic divergence of the trait, according to Mahalanobis (1936).

Considering:

$$
D_{i i^{\prime}}^{2}=\delta^{\prime} \psi^{-1} \delta=\sum_{j=i}^{n} \sum_{j^{\prime}=i}^{n} \omega_{j j^{\prime}} d_{j} d_{j^{\prime}}
$$

Where: $\omega_{j j^{\prime}}$ is the element of the $j^{\text {th }}$ line and $j^{\text {th }}$ column of the inverse matrix of residual variances and covariance.

After determining the canonic variable number, which involves a minimum of $80 \%$ of variation, scores related to it were obtained and used for the traditional dispersion graph, which permitted visualization of divergence among them.

\section{Results and discussion}

There was a predominance of landraces with determinate growth habit type I (Table 1). Earliness 
of flowering and cycle are important traits because they help to avoid or reduce disease or insect pest incidence. Regarding the numbers of days to flowering characteristic (Table 2), reduction in the crop cycle could be obtained by using the cultivars that present growth Type I. When these two characteristics, numbers of days to emergence, numbers of days to flowering were analyzed together, cultivars should receive attention from breeders working for the Mato Grosso do Sul region due to their potential for reducing the emergence and flowering periods. This possibility would allow early cultivars to be obtained, resulting in a better use of the cultivated area by farmers, who could thus obtain a greater number of harvests during a single year. Because yearly maturity is often negatively correlated with seed yield in the common bean (WHITE; SINGH, 1991), these cultivars that maturated early would require further replicated trials across contrasting environments for identification of superior genotypes.

Table 2. Mean square of the analysis of variance of nine morphoagronomic traits of the 35 landraces of common bean from Mato do Grosso do Sul state.

\begin{tabular}{|c|c|c|c|c|c|c|c|c|c|c|}
\hline \multirow{2}{*}{$\begin{array}{l}\text { Sources of } \\
\text { variation }\end{array}$} & \multirow{2}{*}{ df } & \multicolumn{9}{|c|}{ Mean square $^{1 /}$} \\
\hline & & MNDE & NDF & MHFPI & MLLP & TNPP & TNSP & MNSP & MSW & Cycle \\
\hline Blocks & 3 & 1.054 & 0.476 & 4.417 & 0.081 & 39.509 & 1431.875 & 0.442 & 9.506 & 0.578 \\
\hline Cultivars & 34 & $0.431 *$ & $71.952 * *$ & $89.634^{* *}$ & $1.859^{* *}$ & $108.934^{* *}$ & $2991.182 * *$ & $0.915^{* *}$ & $98.301 * *$ & $36.578 * *$ \\
\hline Residual & 102 & 0.245 & 0.868 & 3.665 & 0.256 & 15.918 & 456.322 & 0.162 & 5.687 & 0.465 \\
\hline Mean & & 6.021 & 41.799 & 16.314 & 9.060 & 22.244 & 87.508 & 3.911 & 24.546 & 80.478 \\
\hline $\mathrm{CVe}(\%)$ & & 8.235 & 2.229 & 11.735 & 5.592 & 17.936 & 24.410 & 10.305 & 9.716 & 0.848 \\
\hline
\end{tabular}

${ }^{1 /} \mathrm{MNDE}=$ mean number of days to emergence; NDF = number of days to flowering; MHFPI = mean insertion height of the first pod; MLLP = mean longitudinal length of the pods; TNPP = total number of pods per plant; TNSP = number total of seeds per plant; $\mathrm{MNSP}=$ mean number of seeds per pod; $\mathrm{MSW}=$ mean seed weight; Cycle $=$ cycle; $\mathrm{df}=$ degrees of freedom

**** Significant by the test $\mathrm{F}$ at $1 \%$ and $5 \%$ levels, respectively.

The analysis of variance showed significant differences at the $1 \%$ and $5 \%$ levels of probability for the evaluated characteristics. Table 2 shows the partitioning of the sum of the squares attributed to the genotype effects as well as the means of the squares of the effects for the nine characteristics. The experimental variation coefficient showed $0.84 \%$ amplitude for plant cycle and $24.41 \%$ for total number of seeds per plant. The number of days to emergence, number of days to flowering, longitudinal length of the pods, seed weight, and cycle has demonstrated values for this coefficient below 10\%. The insertion height of the first pod, total number of pods per plant and number of seeds per pod, presented variation in the coefficient, respectively, whose magnitudes were $11.73 \%$, $17.93 \%$ and $10.30 \%$, only the total number of seeds per plant showed a value of $24.41 \%$. These values are less than those reported by Durán et al. (2005), in their morphological and molecular characterization of Caribbean common bean landraces.

The results obtained by the Tocher method showed that one principal group (Group I) was formed by $31.42 \%$ of the cultivars (Table 3 ), all of them from the Mesoamerican gene pool. Groups II, III and IX consisted only of cultivars of Andean origin, whereas the other groups were formed by cultivars with small seeds, since the last ones belong to Mesoamerican gene pool according to Singh, Gepts and Debouck (1991). Thus, it demonstrates that breeding programs in Brazil, and also in other tropical countries, are based on Mesoamerican with limited Andean germplasm introgression (MACIEL; GERALD; ECHEVERRIGARAY, 2001). 
Table 3. Cluster analysis by the Tocher Method, based on the Mahalonobis distance $\left(D_{i i^{\prime}}^{2}\right)$.

\begin{tabular}{cc}
\hline Group & Cultivars $^{1 /}$ \\
\hline I & $17,27,32,28,31,6,4,3,2,5$, and 30 \\
II & $12,21,33,14,29$ and 16 \\
III & $22,24,18$ and 19 \\
IV & 1 and 35 \\
V & 15,25 and 23 \\
VI & 9 and 13 \\
VII & 8,34 and 10 \\
VIII & 20 and 26 \\
IX & 11 \\
X & 7 \\
\hline
\end{tabular}

${ }^{1 /}$ Cultivars were as follows: 1, Rosinha Opaco; 2, Rosinha A; 3, Roxinho A; 4, Carioquinha; 5, Rosado; 6, Roxinho B; 7, Mulatão Lustroso; 8, Bico de Ouro A; 9, Mulatinho Vagem Roxa A; 10, Carioca Bagem Rosada; 11, Jalo; 12, Manteiguinha; 13, Uberabinha Preto; 14, Manteguinha de Cipó; 15, Carioca Novo; 16, Jalo sem Cipó; 17, Carioca sem Cipó; 18, Bodoquena; 19, Chita Bonita; 20, Rosinha sem Cipó; 21, Manteiga sem Cipó; 22, Manteiga com Cipó; 23, Carioca sem Cipó; 24, Bolinha; 25, Mulatinho; Vagem Roxa B; 26, Rosinha B; 27, Roxinho Mineiro; 28, Preto Guamirim; 29, Mantegão; 30, Rosinha C; 31, Rosinha Guaicurus; 32, Cara Suja; 33, Mantega; 34, Bico de Ouro B; and 35, Rosinha D.

The results presented by the Tocher method were in agreement with those obtained by the Generalized Mahalanobis Distance $\left(D_{i i^{\prime}}^{2}\right)$, where the most dissimilar individuals by Mahalanobis were grouped in different clusters. The most divergent landraces were Carioca sem Cipó and Jalo, which are from the Mesoamerican and Andean gene pools, respectively. Moreover, the most similar were the Roxinho Mineiro and Carioca sem Cipó, instead of belonging to different commercial groups, both are of Mesoamerican origin. According to Gaur, Gupta and Kishore (1978), the genetic divergence magnitude is linked with the heterosis level found in the studied species.

Among the landraces which presented higher dissimilarity frequency combination by the Mahalanobis distance were Mantegão, Jalo, Jalo sem Cipó, Uberabinha Preto, Bodoquena, Carioca sem Cipó, and Bico de Ouro B, also grouped in different clusters. This fact indicated that the Tocher method was efficient in distinguishing cultivars from the different gene pools. The use of the genetic dissimilarity measure as a predictable hybrid value at the beginning of breeding programs, where there are a huge number of genotypes, is a very useful tool, because the parents for hybridization, instead of randomized, could be chosen by a genetic divergence study restricting crossings to only more promising combinations with economy in time and work (MALUF; FERREIRA; MIRANDA, 1983; COIMBRA et al., 1999; MACHADO et al., 2002; RIBEIRO; STORCK, 2003).

According to Figure 1, the Tocher and Nearest Neighbor Methods were partially similar. Through the Nearest Neighbor nine groups were formed, although the land races present in Group I contained two subdivisions. These methodologies were in agreement with the cultivars belonging to both the Andean and Mesoamerican gene pools. The Groups I to V, composed by the Nearest Neighbor method, contained cultivars with Mesoamerican origin, whereas Groups from VII to IX only possessed Andean origin. These results were consistent with those obtained by several authors who used Morphoagronomic characters and RAPD markers (SINGH et al., 1991; VILARINHOS et al., 1995; RODIÑO et al., 2003). 
Mahalanobis distance

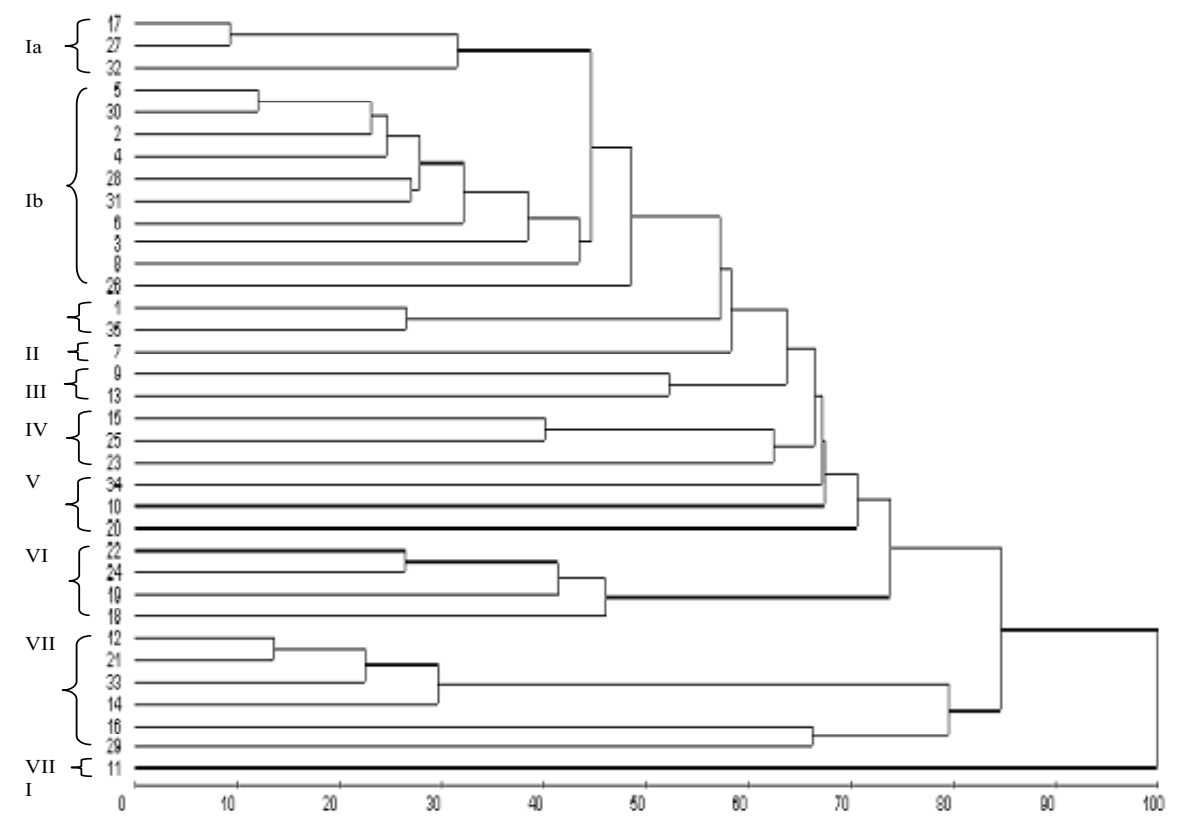

Figure 1. Dendrogram of the 35 landraces of common bean, based on the Nearest Neighbor method, using $D_{i i^{\prime}}^{2}$ as a measure of dissimilarity. Identification numbers for the common bean cultivars are according to Table 3 .

It is possible to observe a great agreement between the two standard clustering methods, based on the results from the grouping analysis, related to the Generalized Mahalanobis Distance. Although the difference presented by the Nearest Neighbor method compared to Tocher method was demonstrated by the replacement of the land races in the Group VIII of Tocher to Group I, Sub-Group I- $b$ and in Group VI with the Nearest Neighbor. It is also considered the changing of the land races Bico de Ouro $A$ of Tocher's Group VII, to Nereast Neighbor method Sub-Group I- $b$.
The Table 4 contains the eigen-values estimative $\left(\lambda_{\mathrm{i}}\right)$ that correspond to the Canonic Variables $\left(\mathrm{VC}_{\mathrm{i}}\right)$ and weighted coefficients (eigen-vectors) associated with the original variables, respectively. Analysis of this table demonstrated that the first and second Canonic Variables explained 54.76\% and 27.14\%, respectively, of the total variation. It was verified that the first two Canonic Variables were sufficient to explain $81.90 \%$ of the total variation observed, which permitted a p-dimensional transposition genetic divergence of bidimensional space $(p=9$, in this case), with despised distortion level caused by distances among the landraces. 
Table 4. Eigenvalues $\left(\lambda_{\mathrm{i}}\right)$ corresponding to variation percentages, explained by Canonic Variables $\left(\mathrm{VC}_{\mathrm{i}}\right)$, and weighted coefficients (eigenvectors) of nine morphoagronomic traits assessed in 35 landraces of common bean.

\begin{tabular}{|c|c|c|c|c|c|c|c|c|c|c|c|}
\hline \multirow[b]{2}{*}{$V C_{i}$} & \multicolumn{2}{|c|}{ Eigenvalues } & \multicolumn{9}{|c|}{ Associated weighted coefficient ${ }^{1 /}$} \\
\hline & $\lambda_{\mathrm{I}}$ & $\begin{array}{c}\text { Acumulated } \\
(\%)\end{array}$ & MNDE & NDF & MHFPI & MLLP & TNPP & TNSP & MNSP & MSW & Cycle \\
\hline $\mathrm{VC}_{1}$ & 54.76 & 54.76 & -0.317 & 0.926 & 0.193 & -0.508 & 0.102 & -0.006 & 0.958 & -0.113 & 0.500 \\
\hline $\mathrm{VC}_{2}$ & 27.14 & 81.90 & -0.304 & -0.438 & -0.078 & 0.227 & -0.078 & 0.004 & 0.007 & 0.038 & 1.384 \\
\hline $\mathrm{VC}_{3}$ & 9.11 & 91.02 & 0.498 & -0.067 & 0.434 & -0.606 & -0.029 & -0.009 & 0.580 & 0.331 & 0.092 \\
\hline $\mathrm{VC}_{4}$ & 3.65 & 64.67 & -0.395 & 0.019 & -0.034 & 2.680 & 0.014 & 0.001 & -2.252 & -0.048 & 0.162 \\
\hline $\mathrm{VC}_{5}$ & 1.89 & 96.56 & -0.370 & 0.122 & 0.015 & -0.853 & 0.252 & -0.011 & -0.096 & 0.225 & 0.045 \\
\hline $\mathrm{VC}_{6}$ & 1.56 & 98.13 & -0.161 & -0.464 & 0.281 & -0.552 & 0.089 & 0.011 & 0.850 & -0.178 & -0.199 \\
\hline $\mathrm{VC}_{7}$ & 0.76 & 98.89 & 1.124 & -0.012 & -0.135 & 0.087 & -0.056 & 0.014 & 1.736 & 0.043 & -0.069 \\
\hline $\mathrm{VC}_{8}$ & 0.65 & 99.55 & -1.030 & 0.016 & -0.006 & -0.110 & -0.413 & 0.098 & -1.876 & 0.075 & 0.036 \\
\hline $\mathrm{VC}_{9}$ & 0.44 & 100.00 & 1.360 & -0.038 & 0.105 & -0.429 & -0.062 & 0.031 & -1.353 & -0.038 & -0.052 \\
\hline
\end{tabular}

${ }^{1 /} \mathrm{MNDE}=$ mean number of days to emergence; NDF = number of days to flowering; MHFPI = mean insertion height of the first pod; MLLP = mean longitudinal length of the pods; TNPP = total number of pods per plant; TNSP = number total of seeds per plant; $\mathrm{MNSP}=$ mean number of seeds per pod; MSW = mean seed weight; CYCLE $=$ cycle.

Based on the graphic dispersion related to the first and second canonic variables, in bidimesional space, it was possible to visualize the relationship among the 35 evaluated land races (Figure 2). The first group in the lower-left part of Figure 2 comprises Manteiguinha, Manteguinha de Cipó, Jalo sem Cipó, Manteiga sem Cipó, Mantegão and Mantega, which are land races characterized as the Manteigão commercial group. On the same side in the upper part, a second group is composed by Bodoquena, Chita Bonita, Manteiga com Cipó, and Bolinha, all of them possessing characteristics similar to those of the Manteigão commercial group, especially in relation to seed size. On the opposite side, the other land races are clustered in groups and sub-groups, which have intermediate and small seeds that are considered the Mesoamerican type.

There was wide genetic divergence, in which the results were in agreement with those presented by the Tocher Method and the Nearest Neighbor method. One especially compact group (Group I) was mostly composed of small black beans (31.43\%), including almost all of the popular Type 2 growth habit that are widely distributed as commercial cultivars.

The results obtained by the Tocher method and the Nearest Neighbor method permitted separation of the land races into Mesoamerican and Andean groups, according to growth habit, seed size and seed shape.

The fidelity of the dispersion graphic technique to identify the most divergent land races was demonstrated in Figure 2, which explained more than $80 \%$ of the total variation of Canonic Variables. The first two Canonic Variables explained $81.90 \%$ of total variation, demonstrating that there was a wide genetic divergence among the 35 landraces evaluated. This fact indicates the possibility of using the land race cultivar as a source of variability for future breeding programs involving crossings.

The clustering methods based on morphoagronomic characteristics showed agreement among the groups formed by the canonic variable analysis, which allowed clustering the landraces according to their centre of origin, either Andean or Mesoamerican. 


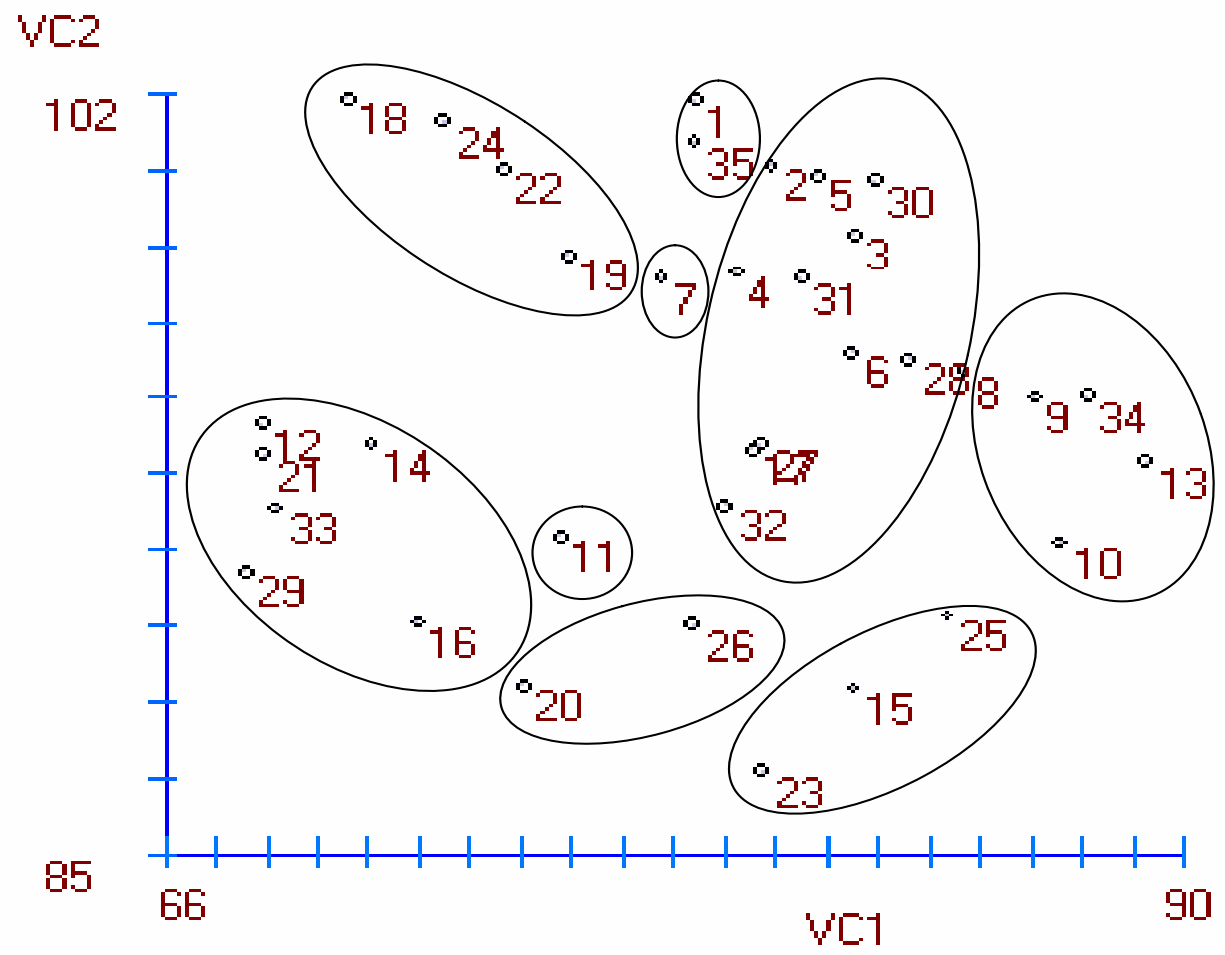

Figure 2. Graphic dispersion of 35 common bean landraces, in relation to the first and second canonic variables $\left(\mathrm{VC}_{1}\right.$ $\mathrm{e} \mathrm{VC}_{2}$ ) of nine characteristics, referred to experiment conducted in Mato Grosso do Sul state. Identification numbers for the common bean cultivars are according to Table 3 .

\section{Conclusion}

The landraces Carioca sem Cipó and Jalo were the most dissimilar for morpho-agronomic traits, whereas Roxinho Mineiro and Carioca sem Cipó were the most similar.

The nine morpho-agronomic characteristics proved to be efficient in discriminating landrace common beans into Andean and Mesoamerican groups. These results reveal a large genetic diversity of the landrace cultivars from Mato Grosso do Sul state. Therefore, it is important to maximize the genetic base of the common bean using through of introduction of landrace cultivars in breeding programs.

\section{Acknowledgements}

This research had the financial support from Conselho Nacional de Pesquisa e Tecnologia (CNPq, Brazil) and Coordenação de Aperfeiçoamento de Pessoal de Nível Superior (Capes).

\section{References}

BEEBE, S.; RENGIFO, J.; GAITAN, E.; DUQUE, M. C.; TOHME, J. Diversity and origin of Andean landraces of common bean. Crop science, Madison, v. 41, n. 3, p. 854-862, 2001.

BEEBE, S.; SKROCH,P. W.; TOHME, J.; DUQUE, M.C.; PEDRAZA, F.; PEDRAZA, F.; NIENHUIS, J. Structure of genetic diversity among common bean landraces of Middle American origin based on correspondence analysis of RAPD. Crop science, Madison, v. 40, n. 1, p. 264-273, 2000. 
CHIORATO,A.F.; CARBONELL, S.A. M.; COLOMBO, C. A.; DIAS, L. A. S.; ITO, M. F. Genetic diversity of common bean accessions in the germplasm bank of the Instituto Agronômico - IAC. Crop Breeding and Applied Biotechnology, Londrina, v. 5, n. 1, p. 1-9, 2005.

COIMBRA, J. L. M.; CARVALHO, F. I. F.; HEMP, S.; OLIVEIRA, A. C.; SILVA, S. A. Divergência genética em feijão preto. Ciência Rural, Santa Maria, v. 29, n. 3, p. 427-431, 1999.

CRUZ, C. D. Programa Genes: versão windows; aplicativo computacional em genética e estatística. Viçosa: Universidade Federal de Viçosa, 2006.

CRUZ, C. D.; CARNEIRO, P. C. S. Modelos biométricos aplicados ao melhoramento genético. Viçosa: Universidade Federal de Viçosa, 2003. v. 2.

CRUZ, C. D.; REGAZZI, A. J. Modelos biométricos aplicados ao melhoramento genético. Viçosa: Universidade Federal de Viçosa, 1994.

DURÁN, L. A.; BLAIR, M. W.; GIRALDO, R.; MACCIAVELLI, E.; PROPHETE, J. C.; BEAVER, J. S. Morphological and molecular characterization of common bean landraces and cultivars from the Caribbean. Crop Science, Madison, v. 45, n. 4, p. 1320-1328, 2005.

GAUR, P. C.; GUPTA, P. K.; KISHORE, H. Studies on genetic divergence in potato. Euphytica, Wageningen, v. 27, n. 3, p. 316-368, 1978.

GONÇALVES, M. C.; MIRANDA, P. Estimates of genetic variability in twelve climbing bean (Phaseolus vulgaris L.) cultivars. Acta Scientiarum, Maringá, v. 5, n. 1, p. 55-63, 1983.

ISLAM, F. M. A.; BASFORD, K. E.; REDDEN, R. J.; GONZALES, A. V.; KROONENBERG, P. M.; BEEBE, $\mathrm{S}$. Genetic variability in cultivated common bean beyond the two major gene pools. Genetic Resources and Crop Evolution, Wageningen, v. 49, n. 3, p. 271-283, 2002.

JOHNSON, R. A.; WICHERN, D. W. Applied multivariate statistical analysis. Englewood Cliffs, New Jersey, 1988.

LOARCE, Y.; GALLEGO, R.; FERRER, E. A comparative analysis of the genetic relationship between rye cultivars using RFLP and RAPD markers. Euphytica, Wageningen, v. 88, n. 2, p. 107-115, 1996.

MACHADO, C. F.; NUNES, G. H. S.; FERREIRA, D. F.; SANTOS, J. B. Divergência genética entre genótipos de feijoeiro a partir de técnicas multivarias. Ciência Rural, Santa Maria, v. 32, n. 2, p. 251-258, 2002.

MACIEL,F.L.;GERALD,L.T.S.;ECHEVERRIGARAY, S. Random amplified polymorphic DNA(RAPD) markers variability among cultivars and land races of common beans (Phaseolus vulgaris L.) of south-Brazil. Euphytica, Wageningen, v. 120, n. 2, p. 257-263, 2001.

MAHALANOBIS, P. C. On the generalized distance in statistics. Proceedings of National Institute of Science of the India, New Delhi, v. 2, n. 1, p. 49-55, 1936.

MALUF, W. R.; FERREIRA, P. E.; MIRANDA, J. E. C. Genetics divergence in tomatoes and its relationship with heterosis for yield in $\mathrm{F}_{1}$ hybrids. Revista Brasileria de Genética, Ribeirão Preto, v. 6, n. 3, p. 453-460, 1983.

McClEAN, P. E.; MYRES, J. M.; HAMMOND, J. J. Coefficient of parentage and cluster analysis of north American dry bean cultivars. Crop Science, Madison, v. 33, n. 1, p. 190-197, 1993.

MIRANDA-LORIGADOS, S.; ROSAS-SOTOMAYOR, J. C.; ARANDA-ROCHA, L. L.; ORTIZ-PÉREZ, L.; PONCE-BRITO, M.; RÍOS-LABRADA, H. Análisis molecular de la diversidad genética de frijol común manejada por campesinos en cuba. Agronomía Mesoamericana, San Jose, v. 17, n. 3, p. 369-382, 2006.

PEREIRA, A. V.; VENCOVSKY, R.; CRUZ, C. D. Selection of botanical and agronomical descriptores for the characterization of cassava (Manihot esculenta Crantz) germoplasma. Revista Brasileira de Genética, Ribeirão Preto, v. 15, n. 1, p. 115-124, 1992.

RIBEIRO, N. D.; STORCK, L. Genitores potenciais para hibridações identificados por divergência genética em feijão carioca. Ciência Rural, Santa Maria, v. 33, n. 3, p. 413-421, 2003.

RODIÑO, A. P.; SANTALlA, M.; DE RON, A. M.; SINGH, S. P. A core collection of common bean from the Iberian Peninsula. Euphytica, Wageningen, v. 131, n. 2, p. 165-175, 2003.

SGARBIERI, V. C.; ANTUNES, P. L.; ALMEIDA, L. D. Nutrional evaluation of four varieties of dry beans (Phaseolus vulgaris L.). Journal Food Science, Malden, v. 44, n. 5, p. 1306-1308, 1979.

SINGH, S. P.; GEPTS, P.; DEBOUCK, D. B. Races of common bean (Phaseolus vulgaris, Fabaceae). Economic Botany, New York, v. 45, n. 3, p. 379-396, 1991.

SINGH, S. P.; GUTIÉRREZ, J.A.; MOLINA, A.; URREA, C.; GEPTS, P. Genetic diversity in cultivated common bean. II. Marker-based analysis of morphological and agronomic traits. Crop Science, Madison, v. 31, n. 2, p. 23-29, 1991.

TANDON, O. B.; BRESSANI, R.; SCRINSHAW, N. S.; LEBEAU, F. Nutrients in Central American beans. Journal of Agriculture Food Chemistry, Washington, v. 5, n. 2, p. 137-142, 1957. 
TEIXEIRA, A. B.; AMARAL JUNIOR, A. T.; RODRIGUES, R.; PEREIRA, T. N. S.; BRESSANSMITH, R. E. Genetic divergence in snap-bean (Phaseolus vulgaris L.) evaluated by different methodologies. Crop Breeding and Applied Biotechnology, Londrina, v. 4, n. 1, p. 57-62, 2004.

VIEIRA, C. Leguminosas de grãos: importância na agricultura e na alimentação humana. Informe Agropecuário, Brasília, v. 16, n. 174, p. 5-11, 1992.
VILARINHOS, A. D.; GONÇALVES-VIDIGAL, M. C.; BARROS, E. G.; PAULA JUNIOR, T. J.; CRUZ, C. D.; MOREIRA, M. A. RAPD-PCR characterization of varieties of the common bean (Phaseolus vulgaris L.) used to identify races of anthracnose fungus (Colletotrichum lindemuthianum). Revista Brasileira de Genética, Ribeirão Preto, v. 18, n. 2, p. 275-280, 1995.

WHITE, J. W.; SINGH, S. P. Sources and inheritance of earliness in tropically adapted indeterminate common bean. Euphytica, Wageningen, v. 55, n. 1, p. 15-19, 1991. 
